\title{
ULSI配線形成におけるステップ式電解波形制御の有効性
}

\author{
小山田 仁子*, 三浦 修平*，本間 英夫**
}

\section{Effectiveness of Stepwise Current Wave Form in ULSI Copper Electroplating}

\author{
Kimiko OYAMADA*, Shuhei MIURA* and Hideo HONMA**
}

*関東学院大学大学院（テ236-8501 神奈川県横浜市金沢区東六浦1-50-1)

**関東学院大学工学部（テ236-8501＼cjkstart神奈川県横浜市金沢区東六浦1-50-1)

*Graduate School, Kanto Gakuin University (1-50-1 Higashi-Mutsuura, Kanazawa-ku, Yokohama-shi, Kanagawa 236-8501)

* *Faculty of Engineering, Kanto Gakuin University (1-50-1 Higashi-Mutsuura, Kanazawa-ku, Yokohama-shi, Kanagawa 236-8501)

\begin{abstract}
Copper electroplating is greatly interested in ULSI technology because of copper damascene process. We have already reported that void-free copper fill can be achieved by the selection of proper additives. However, inclusion of additives in copper deposit may cause deposit deterioration. A possibility of copper filling by the wave form control was examined using additive free bath. The void-free filling can be achieved by current density in stepwise current wave form by changing from lower to higher current.
\end{abstract}

Key Words: ULSI(Ultra-Large Scale Integration), Stepwise Current Wave Form, Copper Electroplating, Damascene process

\section{1. 緒 言}

従来，半導体配線にはPVD法 (Physical Vapor Deposition）やCVD法（Chemical Vapor Deposition）によるド ライプロセスを用いたアルミニウム合金皮膜が使用されて きた。しかし，近年の電子機器の小型軽量化，高性能化に 伴い, さらなる配線の微細化, 高アスペクト比化が求めら れるようになり，アルミニウムよりも比抵抗が低く，エレ クトロマイグレーション耐性に優れた銅が注目されるよう になった。また，1997年 9 月，IBMの電気銅めっきと CMP (Chemical Mechanical Polishing 化学的機械研磨) 技術を組み合わせたダマシンプロセス（Damascene Process）を用いた銅配線デバイスの発表を契機に，配線 に銅を使用する技術が盛んに行われるようになった。

ダマシンプロセスとは，絶縁膜に溝を作り銅を埋め込ん だのち，CMPで表面の平坦化と配線形成を同時に行う方 法で，スパッ夕法，CVD法，めっき法が用いられている。 スパッ夕法においては成膜速度が速く良好な皮膜が得られ るが，アスペクト比が 1 〜 1.5 程度で均一な銅皮膜を得る には限界があり，またCVD法では高アスペクト比でも埋 め込める。しかしながら, 装置や原料のコストが高く成膜 速度が遅いという欠点がある。その点，めっき法はこれら の方法と比ベコストが比較的安価であり，成膜速度も速く 良好な皮膜が得られやすい。最近，銅めっきを用いた半導 体配線形成に関する検討が数多く報告されている ${ }^{1) \sim 4) 。 そ ~}$
こで本研究では, ステップ式電解の，電流波形制御による 半導体配線形成の可能性について検討した。

\section{2. 実験方法}

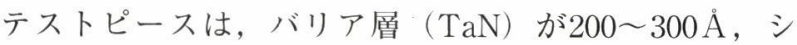
ード層（Cu）が約 $1000 \AA$ ドライプロセスにより成膜され た，トレンチ幅およびビア径 $0.25 \sim 1.0 \mu \mathrm{m}$ ，深さ $0.5 \mu \mathrm{m}$ のパ ターンが形成されているシリコンウエハを利用した（Fig. 1)。めっき浴は一般的にプリント配線板で用いられる硫 酸銅ハイスロー浴（Table 1 ），装飾めっきなどに用いら

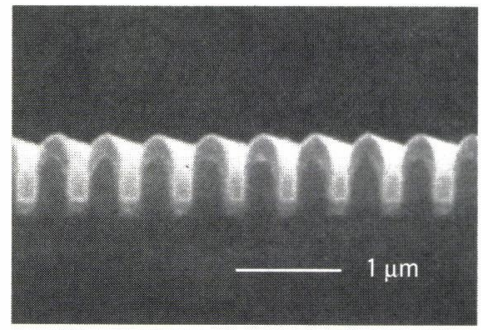

Fig.1 Cross sectional image of sample

Table 1. High throwing bath composition and operating conditions

\begin{tabular}{lr}
$\mathrm{CuSO}_{4} \cdot 5 \mathrm{H}_{2} \mathrm{O}$ & $65 \mathrm{~g} / \mathrm{dm}^{3}$ \\
$\mathrm{H}_{2} \mathrm{SO}_{4}$ & $200 \mathrm{~g} / \mathrm{dm}^{3}$ \\
$\mathrm{Cl}^{-}$ & $50 \mathrm{mg} / \mathrm{dm}^{3}$ \\
Additives & \\
\hline Additation & Air gas bubbling \\
Bath temperature & $25^{\circ} \mathrm{C}$ \\
\hline
\end{tabular}


Table 2. Decorative bath composition and operating conditions

\begin{tabular}{lr}
$\mathrm{CuSO}_{4} \cdot 5 \mathrm{H}_{2} \mathrm{O}$ & $200 \mathrm{~g} / \mathrm{dm}^{3}$ \\
$\mathrm{H}_{2} \mathrm{SO}_{4}$ & $50 \mathrm{~g} / \mathrm{dm}^{3}$ \\
$\mathrm{Cl}^{-}$ & $50 \mathrm{mg} / \mathrm{dm}^{3}$ \\
Additives & \\
\hline Agitation & Air gas bubbling \\
Bath temperature & $25^{\circ} \mathrm{C}$ \\
\hline
\end{tabular}

れる硫酸銅一般浴（Table 2 ）を使用した。陽極には含リ ン銅を使用し，陽極と陰極間距離は $1 \mathrm{~cm}$ で固定した。テ

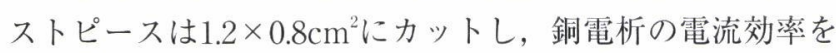
ほぼ $100 \%$ として $1 \mu \mathrm{m}$ 成膜するのに必要なクーロン数を算 出し, めっきを行った。評価方法はSEM（走査型電子顕 微鏡）を用い，断面観察により埋め込み性を評価した。

\section{3. 実験結果および考察}

\section{1 直流電解}

半導体配線の形成において, 析出銅皮膜の特性は低抵抗 で，平滑性に優れた皮膜が求められる。著者らは前報で直 流電解を用い添加剂を制御することにより，ボイドがなく 平滑性に優れた皮膜が得られることを報告しだ。しかし， 添加剂を加えないとFig. 2 に示したように，配線内部にボ イドやシームなどの欠陷が生じた。ボイドやシームのでき る原因として，ビアおよびトレンチ上部の非線形部分に電 流線が集中することで，コーナ部の析出が優先的に起こる ことが考えられる。

\section{2 ステップ式電解}

直流電解では添加剂を使用しないと, 非線形部分の析出 が優先的に起こり，ボイドやシームなど配線内部の欠陉が 生ずることをすでに述べたが, 低電流密度では, 比較的埋 め达み性が良くなるが，表面の凹凸が激しく埋め达みまで の時間がかかった。一方, 高電流密度では表面は平滑で時 間は短縮されたが，ボイドが発生することがわかった。

そこで, 電解初期は低電流密度で成膜し, その後高電流 密度で成膜することで, 良好な埋め込みおよび表面の平坦 化が可能ではないかと考え, 電流密度を $0.1 \mathrm{~A} / \mathrm{dm}^{2}$ から 3

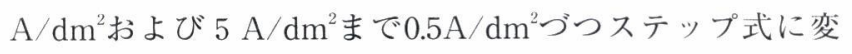
化させて成膜を行った。低電流密度から同一時間でステッ プ状に電流密度を上昇させた場合は, 八イスロー浴および 一般浴ともボイドが発生し良好な埋め込みを得ることがで

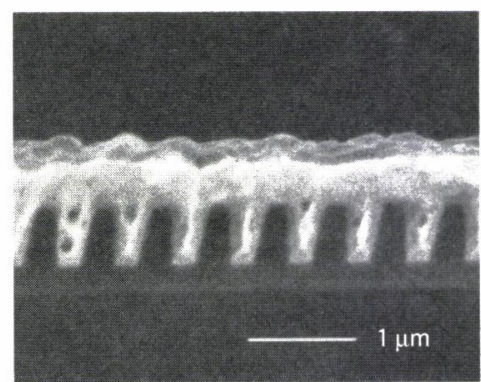

Fig.2 Cross sectional image of trenches by direct current plating without additives

きなかった (Fig. 3 )。一方，テストピースの面積から 1

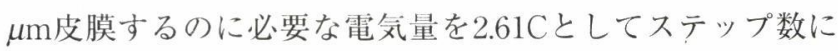
合わせて電気量を割りふった。0.372C流すごとにステップ 状に0.1A $/ \mathrm{dm}^{2}$ から $3 \mathrm{~A} / \mathrm{dm}^{2}$ まで総クーロン量 $2.61 \mathrm{C}$ 通電し た結果，一般浴ハイスロー浴共に比較的良好な埋め达みが 得られたが, $0.237 \mathrm{C} の$ 電気量をステップ状に0.1 A $/ \mathrm{dm}^{2}$ か

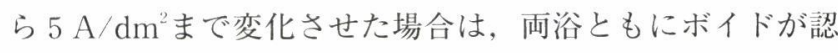
められた (Fig. 4)。

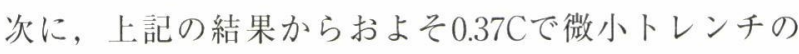
80\%ほどが埋め达まれたことから, 初期に低電流密度 $0.1 \mathrm{~A} / \mathrm{dm}^{2}$ で0.37C電解を行った後, より平坦な表面を得る

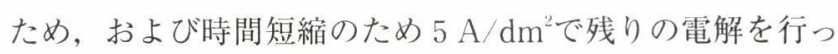
た（Fig. 5 ）。一般浴ではボイドが羿められたが，八イス ロー浴では良好な埋め迄みが得られた。これは, 低電流密 度でのめっきで微小なトレンチが充てん, もしくは深さが 減少することで, 全体的にアスペクト比が一定になり, 良 好な埋め込みが得られたと考えられる。以上の結果から， 初期の低電流密度での成膜時間が重要な要素であると考え られる。

\section{4. 結 語}

電気銅めっきによる半導体配線の埋め达みに対しては, めっき液中に添加剤を加えて形成されているが, 本研究公 では, 添加剂無添加の硫酸銅めっきを用いて, ダマシンプ ロセスによる半導体配線形成について検討を行い, つぎの 結論を得た。直流電解を行うと, ボイドやシームなどの久 陥が発生するが, 電解初期は低電流密度で成膜し, その後 高電流密度で成膜するという, ステップ式電解を行うこと で埋め达み性の改善が得られた。またその場合, 低電流密

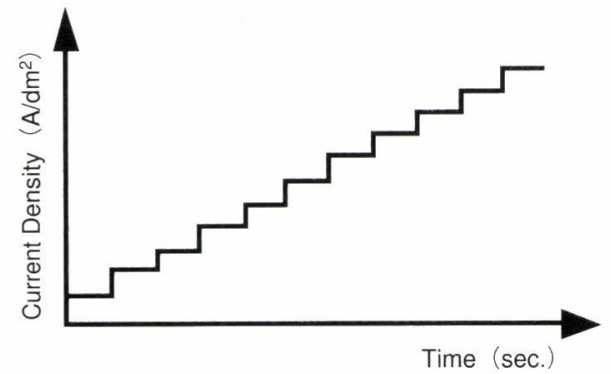

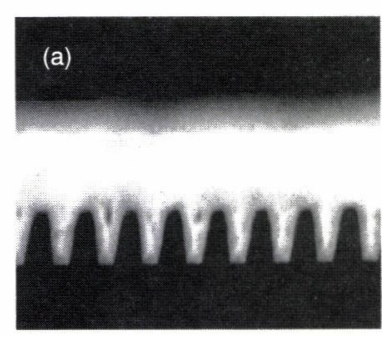

(a) Decorative bath (b)
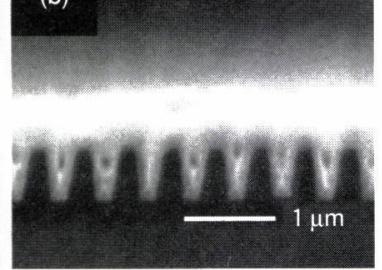

(b) High throwing bath

Fig.3 Cross sectional images of trenches by changing wave form in stepwise 

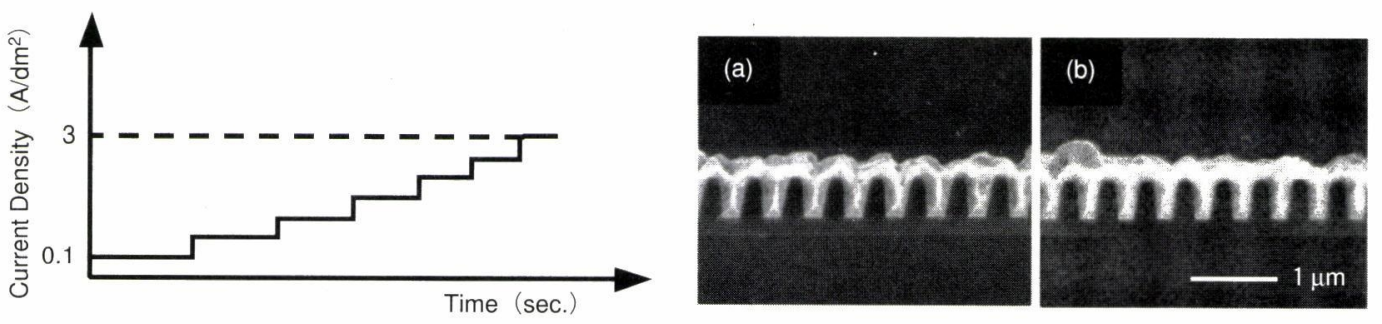

(1) $0.1-3 \mathrm{~A} / \mathrm{dm}^{3}$
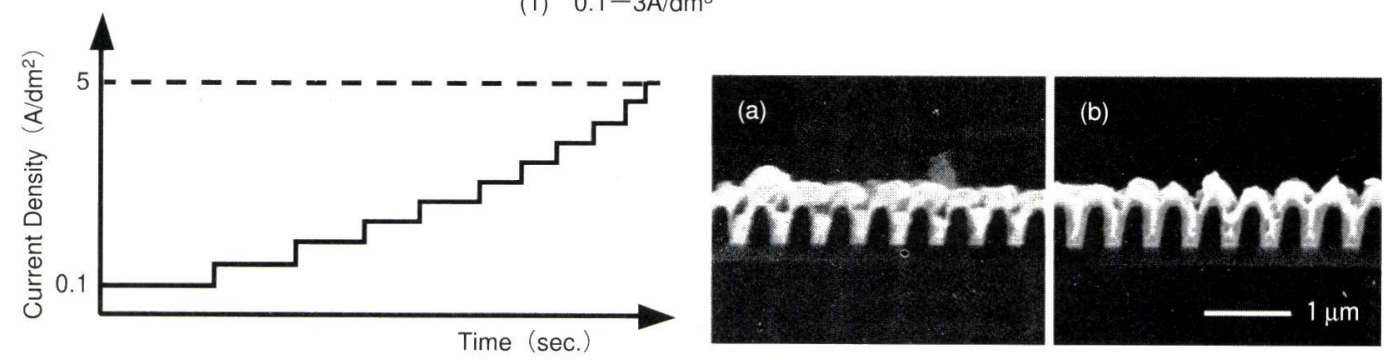

(2) $0.1-5 \mathrm{~A} / \mathrm{dm}^{3}$

Fig.4 Cross sectional images of trenches by changing wave form 〔(a) Decorative bath, (b) High throwing bath
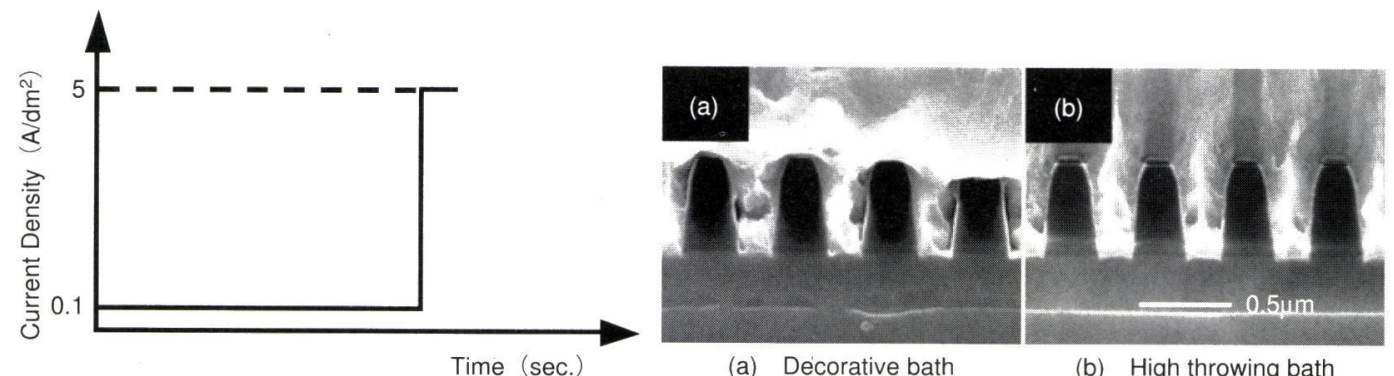

(a) Decorative bath

(b) High throwing bath

Fig.5 Cross sectional images of changing electric current density

度での初期の成膜時間がボイドフリーの埋め込みを得るた めに重要な要素であると示唆された。

(2001.7.25-受理２001.10.23-再受理)

$$
\text { 文献 }
$$

1)上野和良：“微細Cu配線プロセスにおける成膜技術の現状 と課題”，表面技術，Vol.49，No.11，pp.1171-1175， 1998

2) 縄舟秀美：“湿式銅めっき法によるULSI配線技術の課題”, 表面技術，Vol.49，No.11，pp.1180-1184， 1998

3) R.D.Mikkola, Q-T.Jiang and B.Carpenter : “Copper Elec- troplating for Advanced Interconnect Technology", PLATING \& SURFACE FINISHING, pp.81-85, March 2000

4) Jonathan Reid and Steven Mayer: "Formation of Submicron Scale Features Using Electroplated Copper", AESF SUR/FIN, June26-29, 2000 Proceedings

5) 高田祐一, 小山田仁子, 三浦修平, 本間英夫 : “電気銅めっ きによるULSI配線形成”, エレクトロニクス実装学会誌, Vol.4, No.3, pp.219-224, 2001 